Jurnal Kesehatan Terpadu (Integrated Health Journal)

Vol. 11 No. 2, November 2020 (65-70)

ISSN 1978-7766 (Print) and ISSN 2597-9566 (Online)

Journal homepage: https://www.jurnalpoltekkesmaluku.com/index.php/JKT

\title{
Hubungan Obesitas, Status Paritas, dan Status Gravida dengan Kejadian Anemia dalam Kehamilan di Puskesmas Rijali
}

The Correlation between Obesity, Gravida Status, and Parity Status towards Anemia in Pregnancy in Puskesmas Rijali

\author{
Muhammad Sobri Maulana ${ }^{1}$ \\ ${ }^{1}$ Profesi Dokter Pendidikan Dokter, Fakultas Kedokteran Universitas Indonesia, \\ Jalan Salemba Raya, Jakarta Pusat, DKI Jakarta \\ E-mail Korespondensi: muhammadsobrimaulana31@gmail.com
}

\begin{abstract}
Anemia in pregnancy is diagnosed when $\mathrm{Hb}<11 \mathrm{~g} / \mathrm{dL}$ or $\mathrm{Ht}<33 \%$. Anemia itself is caused by multifactorial, one of those are nutrition and pregnancy history. This study aims to identify the correlation between obesity, parity status and gravida status towards the number of anemia in pregnancy. This study used cross-sectional design which involved 146 pregnant women in Puskesmas Rijali. The variables such as BMI, parity status and gravida status are gathered using random sampling. The variables then are calculated using SPSS. The data is shown in the form of categorical variable after calculated using chi-square methods. This study shows no correlation between obesity and parity status with anemia in pregnancy $(\mathrm{p}>0.05)$. This result is supported by some others studies. In the other hand, this study shows correlation between gravida status and anemia during pregnancy $(\mathrm{p}<0.05)$. And the result is also supported by many others studies, one of the reason is due to malnutrition and blood loss during the previous delivery process. This study shows correlation between gravida status and anemia during pregnancy. Meanwhile, parity status and obesity doesn't show any significant correlation.
\end{abstract}

Keywords: Anemia in pregnancy, gravida status, obesity, parity status

\begin{abstract}
ABSTRAK
Anemia pada kehamilan ditegakkan apabila kadar hemoglobin ibu kurang dari $11 \mathrm{~g} / \mathrm{dl}$ atau hematokrit kurang dari 33\%. Anemia sendiri disebabkan oleh multifactor, salah satunya nutrisi dan riwayat kehamilan. Penelitian ini ditujukan untuk mengetahui beberapa factor yang mungkin berpengaruh seperti IMT, status paritas dan gravida. Penelitian ini dilakukan menggunakan metode potong lintang di Puskesmas Rijali dengan total subjek 146 orang. Pengambilan subjek dilakukan secara random sampling. Data berupa IMT ibu, status paritas dan gravida diolah menggunakan SPSS. Data kemudian ditampilkan dalam variabel kategorik setelah diolah menggunakan uji chi-square. Hasil penelitian menunjukkan tidak terdapat hubungan yang bermakna antara obesitas dan status paritas dengan kejadian anemia dalam kehamilan $(\mathrm{p}>0,05)$. Hasil tersebut ternyata sesuai dengan hasil beberapa penelitian sebelumnya. Di sisi lain, terdapat hubungan bermakna antara status gravida dengan kejadian anemia dalam kehamilan $(\mathrm{p}<0,05)$. Hasil ini juga sesuai dengan penelitian sebelumnya yang mana salah satu alasan terdapatnya hubungan tersebut adalah malnutrisi dan perdarahan yang dialami ibu saat persalinan sebelumnya. Penelitian menunjukkan adanya hubungan antara status gravida terhadap kejadian anemia pada ibu hamil. Sementara status paritas dan obesitas ibu hamil sebelum kehamilan tidak memiliki hubungan.
\end{abstract}

Kata kunci: Anemia kehamilan, obesitas, status gravida, status paritas 


\section{PENDAHULUAN}

Anemia pada kehamilan didefinisikan sebagai penurunan kadar hematokrit, konsentrasi hemoglobin dan/atau hitung eritrosit hingga mencapai nilai dibawah batas normal. Pada umumnya, anemia saat kehamilan ditegakkan apabila kadar hemoglobin ibu kurang dari $11 \mathrm{~g} / \mathrm{dl}$ atau hematokrit kurang dari 33\%. ${ }^{1,3}$ Dari data World Health Organization, sebanyak $35-75 \%$ ibu hamil di negara berkembang dan $18 \%$ di negara maju mengalami anemia. Sementara di Indonesia, berdasarkan Riskesdas tahun 2018, diperkirakan 45\% ibu hamil mengalami anemia, dengan setengahnya disebabkan oleh faktor defisiensi zat besi. ${ }^{1,2}$ Anemia pada ibu hamil akan memberikan beberapa dampak negatif baik terhadap ibu maupun bayi, seperti meningkatkan risiko kematian ibu saat melahirkan, risiko BBLR, risiko bayi prematur, dan infeksi intrauterin. ${ }^{1-3}$

Anemia pada kehamilan merupakan kelainan hematologik yang bersifat mutifaktorial, artinya melibatkan interaksi dari beberapa faktor baik dari faktor sosial, genetik yaitu riwayat keluarga, biologis (misalnya riwayat penyakit kronis), dan nutrisi seperti defisiensi besi serta asam folat. ${ }^{1-3}$ Kementerian Kesehatan Republik Indonesia telah mengeluarkan kebijakan berupa suplementasi besi basi, setidaknya 90 pil zat besi, selama kehamilan. Namun demikian, menurut data Riskesdas 2013, bahwa masih banyak ibu hamil yang belum bisa diklarifikasi apakah benar-benar mengonsumsi suplementasi besi yang diberikan. ${ }^{3}$ Oleh karena itu, berdasarkan hasil tersebut, Kemenkes RI menyatakan bahwa target pencegahan anemia pada ibu hamil dengan suplementasi zat besi tidak terpenuhi. ${ }^{3}$ Dari data bulan November 2017 hingga Januari 2019 yang tercatat di Puskemas Rijali, terdapat 146 ibu hamil yang terdiagnosis mengalami anemia selama kehamilan. Berdasarkan data tersebut, terlihat beberapa faktor yang menurut kami mungkin memiliki pengaruh terhadap tingginya angka kejadian anemia pada ibu hamil di Puskesmas Rijali. Pertama, indeks masa tubuh ibu hamil sebelum mengalami kehamilan umumnya lebih dari $30 \mathrm{~kg} / \mathrm{m}^{2}$, yaitu tergolong obesitas. Kedua, ibu hamil di Puskemas Rijali rata-rata bukan hamil anak pertama, bahkan sebagian besar sudah pernah hamil dan melahirkan lebih dari 2 kali.

Dengan mengetahui keterkaitan faktor tersebut dengan anemia pada ibu hamil, diharapkan para petugas kesehatan dapat melakukan upaya pencegahan peningkatan angka anemia pada ibu hamil dengan mengambil langkah yang tepat.

\section{METODE PENELITIAN}

Penelitian ini menggunakan desain penelitian potong lintang yang dilakukan pada tanggal 8-10 Januari 2020 di Puskesmas Rijali, Maluku. Data penelitian diperoleh dari rekam medis pasien poliklinik kesehatan ibu dan anak (KIA) Puskesmas Rijali dari bulan November 2017 hingga Januari 2018. Populasi target penelitian ini adalah seluruh pasien hamil dan populasi terjangkau adalah seluruh pasien poliklinik KIA Puskesmas Rijali, Maluku yang telah melaksanakan kunjungan pada kehamilan trimester ke-3 pada bulan November 2017 hingga Januari 2018. Total subjek penelitian ini adalah 146 subjek yang memenuhi kriteria inklusi dan eksklusi. Pemilihan subjek dilakukan secara random sampling. Kriteria inklusinya adalah pasien Poliklinik KIA Puskesmas Rijali yang rutin melaksanakan kunjungan antenatal, catatan kunjungannya yang tercatat lengkap pada rekam medis Puskesmas dan pasien dengan usia kehamilan minimal memasuki trimester ketiga. Kriteria eksklusi yaitu pasien yang memiliki faktor penyulit lain seperti hipertensi dalam kehamilan ataupun infeksi dalam kehamilan. Data berupa indeks massa tubuh (IMT) ibu sebelum hamil, status paritas, status gravida dan adanya anemia dalam kehamilan pada setiap pasien, dicatat untuk kemudian diolah menggunakan program SPSS. IMT ibu dikategorikan menjadi dua kategori yaitu normal (IMT 18,5-22,9 $\mathrm{kg} / \mathrm{m}^{2}$ ) dan overweight/obesitas (IMT $\geq 23 \mathrm{~kg} / \mathrm{m}^{2}$ ). Status paritas juga dikategorikan menjadi dua kategori yaitu nulipara dan multipara serta status gravida dibagi menjadi dua kategori yaitu primigravida/sekundigravida dan multigravid. Data ditampilkan dalam variabel kategorik untuk melihat kebermaknaan hubungan antara obesitas, status paritas dan status gravida 
dengan kejadian anemia dalam kehamilan. Analisis statistik dilakukan dengan memasukkan data ke program SPSS dan menggunakan uji chi-square.

\section{HASIL}

Sebagian besar subjek penelitian memiliki usia diantara 20-35 tahun $(90,4 \%)$, yang menunjukkan bahwa secara keseluruhan subjek penelitian memiliki rentang usia yang homogen sehingga dapat disimpulkan bahwa usia sebagai variabel perancu dalam penelitian ini memiliki efek yang cukup kecil. Sebagian besar subjek penelitian memiliki riwayat pendidikan terakhir SMA/SMK dan SMP. Subjek penelitian yang memiliki nilai IMT $\geq 28$ $\mathrm{Kg} / \mathrm{m}^{2}$ adalah $33,6 \%$, subjek multipara berjumlah $74,7 \%$ dan subjek multigravida berjumlah $34,2 \%$ dari seluruh subjek penelitian (Tabel 1).

Tabel 1. Karakteristik Subjek Penelitian

\begin{tabular}{cc}
\hline Variabel & $\mathbf{N}(\%)$ \\
\hline Usia & $2(1,4 \%)$ \\
20 tahun & $132(90,4 \%)$ \\
$>35$ tahun & $12(8,2 \%)$ \\
& \\
Pendidikan & \\
Tamat SD & $14(9,6 \%)$ \\
Tamat SMP & $30(20,5 \%)$ \\
Tamat SMA/SMK & $87(59,6 \%)$ \\
Tamat D3/S1 & $15(10,3 \%)$ \\
& \\
Indeks Massa Tubuh & $97(66,4 \%)$ \\
Normal & $49(33,6 \%)$ \\
Overweight/Obesitas & \\
& \\
Status paritas dan Gravida & $37(25,3 \%)$ \\
Nullipara & $109(74,7 \%)$ \\
Multipara & $96(65,8 \%)$ \\
Primigravida/sekundigravida & $50(34,2 \%)$ \\
Multigravida &
\end{tabular}

Tabel 2. Hasil Uji Statistik Hubungan Obesitas dan Kejadian Anemia

\begin{tabular}{|c|c|c|c|}
\hline Indeks Massa Tubuh & \multicolumn{2}{|c|}{ Kejadian Anemia } & Uji Statistik \\
\hline & Anemia & Normal & \\
\hline Overweight/Obesitas & 33 & 62 & Uji Chi-Square \\
\hline Normal & 21 & 30 & $P=0,442$ \\
\hline
\end{tabular}

Tabel 3. Hasil Uji Statistik Hubungan Status Paritas dan Kejadian Anemia

\begin{tabular}{|c|c|c|c|}
\hline \multirow{2}{*}{ Status Paritas } & \multicolumn{2}{|c|}{ Kejadian Anemia } & Uji Statistik \\
\hline & Anemia & Norma & \\
\hline Multipara & 42 & 67 & Uji Chi-Square \\
\hline Nulipara & 12 & 25 & $\mathrm{P}=0,507$ \\
\hline
\end{tabular}


Tabel 4. Hasil Uji Statistik Hubungan Status Gravida dan Kejadian Anemia

\begin{tabular}{|c|c|c|c|}
\hline \multirow[t]{2}{*}{ Status Gravida } & \multicolumn{2}{|c|}{ Kejadian Anemia } & Uji Statistik \\
\hline & Anemia & Normal & \\
\hline Multigravida & 24 & 26 & Uji Chi-Square \\
\hline Primi/Sekundigravida & 30 & 66 & $P=0,047$ \\
\hline
\end{tabular}

Tabel 2 menunjukkan bahwa tidak terdapat hubungan yang bermakna antara obesitas dengan kejadian anemia dalam kehamilan ( $p>0,05)$. Tabel 3 memperlihatkan bahwa status paritas juga tidak memiliki hubungan yang bermakna dengan kejadian anemia dalam kehamilan $(p>0,05)$. Tabel 4 menunjukkan adanya hubungan bermakna antara status gravida dengan kejadian anemia dalam kehamilan $(\mathrm{p}<0,05)$, multigravida memiliki hubungan yang signifikan dengan kejadian anemia dalam kehamilan.

\section{BAHASAN}

Sebagian besar usia ibu hamil berada dalam kategori berisiko rendah, yaitu dalam rentang usia 20-35 tahun. Proporsi tingkat pendidikan terakhir yang paling banyak adalah SMA/SMK $(60 \%)$. Tingkat pendidikan dapat meningkatkan pengetahuan terhadap anemia disertai kesadaran lebih dalam pemantauan kehamilan sehingga diharapkan adanya pemahaman mengenai perilaku pencegahan anemia terutama saat kehamilan. ${ }^{4}$ Penelitian ini menunjukkan sebanyak $37 \%$ subjek penelitian memiliki anemia pada masa kehamilannya. Angka kejadian anemia pada ibu hamil tersebut serupa dengan proporsi kejadian anemia pada ibu hamil menurut Riskesdas tahun 2013. ${ }^{3}$ Subjek wanita hamil dengan overweight/obesitas memiliki kejadian anemia sebesar 35\% sedangkan sebanyak 41\% subjek dengan IMT normal mengalami anemia pada kehamilan. Prevalensi obesitas pada penelitian ini lebih tinggi daripada prevalensi obesitas wanita usia $>18$ tahun berdasarkan Riskesdas 2013, yaitu 33\%. ${ }^{3}$ Kejadian anemia pada populasi penelitian ini tidak sesuai dengan penelitian oleh Ahmed tahun 2009 di Mesir menunjukkan bahwa anemia terjadi lebih sering di wanita obesitas dibandingkan dengan yang tidak. ${ }^{5}$

Obesitas dapat menyebabkan rendahnya zat besi dalam tubuh karena orang obese cenderung mengkonsumsi makanan tinggi energi namun rendah nutrisi sehingga asupan zat besi juga rendah. Penelitian Ahmed, 2009 menyebutkan bahwa peningkatan IMT berhubungan dengan penurunan status zat besi dalam tubuh. Inflamasi kronik dalam kehamilan juga lebih berisiko pada ibu obesitas akibat adanya jaringan lemak yang berlebih. Lemak yang berlebih ini dapat juga mengganggu absorpsi zat besi dalam tubuh. ${ }^{6}$ Pada penelitian ini, ditemukan tidak ada hubungan antara obesitas dengan kejadian anemia (Tabel 2). Hal ini sesuai dengan hasil yang ditemukan pada penelitian Sadanandan tahun 2019 di India walaupun dikatakan bahwa hasil tersebut tidak sesuai dengan teori yang sebelumnya telah dikemukakan. ${ }^{7}$ Meskipun tidak ditemukan hubungan bermakna, pemantauan berat badan ibu hamil selama masa kehamilan harus tetap dilakukan setiap bulan untuk menggambarkan status gizi ibu hamil. Kurangnya peningkatan BB selama kehamilan dapat menjadi indikasi adanya malnutrisi dan meningkatkan risiko terhambatnya pertumbuhan janin.

Subjek nulipara memiliki kejadian anemia sebanyak 32\% sedangkan subjek multipara memiliki angka kejadian anemia sebanyak $38,5 \%$. Kejadian anemia yang lebih tinggi pada subjek multipara sesuai dengan penelitian sebelumnya oleh Astriana pada tahun 2017 pada ibu hamil di Sumatera Selatan. ${ }^{8}$ Hasil penelitian ini menunjukkan tidak adanya hubungan bermakna antara status paritas ibu dengan kejadian anemia dalam kehamilan (Tabel 3). Hasil ini berkebalikan dengan penelitian yang sebelumnya dilakukan oleh Sadanandan tahun 2019 di India. ${ }^{7,10} \mathrm{Hal}$ ini mungkin terjadi akibat pengelompokkan paritas yang berbeda. Penelitian yang menunjukkan hubungan bermakna antara paritas dan kejadian anemia menyatakan kategori paritas tinggi ( $\geq 5$ ) yang dapat meningkatkan risiko anemia pada kehamilan. ${ }^{10-12}$ Akan tetapi, terdapat penelitian oleh Simkodi Nigeria yang menyatakan bahwa tidak ada hubungan 
signifikan antara paritas dengan anemia pada kehamilan. Hal tersebut dapat disebabkan oleh adanya penurunan wanita dengan paritas berisiko tinggi sehingga perlu dilakukan pengawasan anemia secara periodik. Suplementasi rutin pada wanita hamil dengan multipara juga dapat memengaruhi kejadian anemia dan hubungannya dengan paritas.

Sebanyak $31 \%$ wanita primigravida atau sekundigravida yang mengalami anemia pada kehamilan, sedangkan pada wanita multigravida terdapat sebanyak $50 \%$. Hal ini sesuai dengan penelitian Melchor tahun 2019 dengan populasi ibu hamil di Jerman. Dalam penelitiannya dinyatakan hasil tersebut sesuai dengan teori semakin banyak zat besi yang hilang seiring meningkatnya kehamilan dan persalinan. ${ }^{9}$ Hasil analisis hubungan antara gravida dan anemia pada kehamilan menunjukkan adanya hubungan bermakna diantara keduanya $(\mathrm{p}<0,05)$. Hal ini sesuai dengan penelitian yang dilakukan oleh Alene di Ethiopia tahun 2014 yang menyatakan teori serupa. ${ }^{9}$

Peningkatan risiko anemia pada multigravida disebabkan oleh semakin berkurangnya cadangan zat besi ibu akibat peningkatan kebutuhan nutrisi setiap kehamilan dan kehilangan darah saat masa nifas. ${ }^{9}$

Nutrisi ibu yang ikut terbagi bersama janin selama kehamilan juga dapat meningkatkan risiko terjadinya anemia. Oleh karena itu, perlu dilakukan pemantauan mengenai asupan nutrisi serta suplementasi zat besi yang adekuat terutama pada ibu dengan multigravida.

\section{SIMPULAN}

Perbedaan yang didapatkan pada setiap hasil pada penelitian ini dapat terjadi akibat adanya faktor lain yang memengaruhi anemia pada kehamilan, seperti faktor sosiodemografik dan sosioekonomi yang tidak dilakukan penyesuaian dalam analisis data. Perbedaan karakterisik populasi penelitian, seperti etnis, juga memungkinkan ditemukannya perbedaan dalam hasil penelitian. Keterbatasan data yang tersedia juga dapat memengaruhi hasil penelitian.

\section{SARAN}

Dibutuhkan penelitian lebih lanjut mengenai hubungan antara obesitas, paritas, dan gravida dengan kejadian anemia pada ibu hamil agar dapat ditarik kesimpulan yang lebih baik.

\section{RUJUKAN}

1. Prawirohardjo S. Ilmu kebidanan. Jakarta : PT Bina Pustaka Sarwono Prawirohardjo; 2019.

2. Buku saku pelayanan kesehatan ibu di fasilitas kesehatan dasar dan rujukan. Jakarta : Kementerian Kesehatan RI; 2019.

3. Riset Kesehatan Dasar 2018 [Internet]. Jakarta: Kemenkes RI; 2018 [cited 2020 Sep 16].

4. Vindhya J, Nath A, Nurthy GV, Metgud C, Sheeba B, Shubhashree V, Srinivas P. Prevalence and risk factors of anemia among pregnant women attending a public-sector hospital in Bangalora, South India. J Family Med Prim Care. 2019 Jan;8(1): 37-43 DOI. 10.4103/jfmpc.jfmpc_265_18

5. Melchor I, Burgos J, Campo A, Aiartzaguena A, Julieta G, Juan C. Effect of maternal obesity on pregnancy outcomes in women delivering singleton babies: a historical cohort study. Journal of Perintala Medicine. 2019 ;47(6) DOI. 10.1515/jpm-2019-0103

6. Simko M, Totka A, Vondrova D, Samohyl M, Jurkovica J, Michal T, Cibulkova A, Stofko J, Argalasova L. Maternal body mass index and gestational weight gain and their association with pregnancy complications and perinatal conditions. Int J Environ Res Public Health. 2019 May;16(10):1751 DOI. 10.3390/ijerph16101751

7. Sadanandan K, Kurian S, Valliot B, Sasdharan A, Sherin N, Madhu R, Ramesh S, Mondain S. Prevalence of gestational hypertension and factors influencing selection of anti-hypertensive drugs in pregnancy. Journal of Hypertension. 2109 Jul;23(2)

8. Astriana, Willy. (2017). Kejadian Anemia pada Ibu Hamil Ditinjau dari Paritas Dan Usia. Jurnal Aisyah: Jurnal Ilmu Kesehatan. 2 (2), 123 - 130. 
9. Khai T, McCormack S. Screening and Treatment of Obstetric Anemia: A Review of Clinical Effectiviess, Cost-Effectiveness and Guidelines. CADTH. 2019 